\title{
EVALUATION OF DIFFERENTIAL SERUM EXPRESSION OF THREE FACTORS AND PULMONARY FUNCTION IN PATIENTS WITH SILICOSIS
}

\author{
YING ZHU, XIA YU DUAN, YUN QI CHENG, XIN JING YAO, HONG XU, KUI SHENG ZHANG, FENG SHI LI, \\ FANG YANG, LIANG HE LIU, and XIANG JU YUAN
}

North China University of Science and Technology, Tangshan, China

School of Public Health

\begin{abstract}
Objectives: Silicosis is a chronic occupational lung disease. As was previously found by the authors, some proteins increased in the lung tissue of activated rats, and protein tyrosine phosphatase non-receptor type 2 (PTPN2), factor B, and vaccinia-related kinase 1 (VRK1) showed highly differential expressions. Material and Methods: In this study, serum and bronchoalveolar lavage fluid samples were collected from patients with silicosis and healthy people to verify the expression of PTPN2, factor B, and VRK1. The diagnostic value of differentially expressed proteins for silicosis was judged. Results: The expression levels of serum PTPN2, VRK1, and factor B in patients with silicosis were significantly higher than those in the control group $(\mathrm{p}<0.01)$. Higher serum PTPN2 and factor B concentrations significantly and negatively correlated with the ratio of forced expiratory volume in $1 \mathrm{~s}$ to forced vital capacity $\left(\mathrm{FEV}_{1} / \mathrm{FVC}\right)$, maximum vital capacity $\left(\mathrm{VC}_{\max }\right), \mathrm{FEV}_{1}$, and $\mathrm{FVC}$, suggesting that the high expression of PTPN2 and factor B is associated with decreased pulmonary ventilation function and restrictive ventilatory impairment in patients with silicosis. All area under curve (AUC) measurements generated from single detection events were $>0.744$, with PTPN2 reaching the highest value $(0.858)$. The AUC, sensitivity, and specificity for the combined diagnosis using factor B and PTPN2 were $0.907,86.91 \%$ and $85.07 \%$, respectively, for factor B and PTPN2. The 3 differentially expressed proteins are potential classes of predictive biomarkers for silicosis. Conclusions: Regarding the economy and test practicality, the best diagnostic combination is factor B and PTPN2 for the analysis of AUC, sensitivity and specificity. Int J Occup Med Environ Health. 2021;34(4):527-40
\end{abstract}

Key words:

silicosis, pulmonary function, early diagnosis, ROC, PTPN2, factor B

\section{INTRODUCTION}

Silicosis is a condition with a high incidence by occupation. It is a consequence of the prolonged inhalation of crystalline silica particles into the lungs, which thereby enter the distal air chambers. In developing countries, such as China, the complete control and prevention of silicosis is unrealistic in the short term [1]. Patients with silicosis not only lose their livelihood but also have a shorter life expectancy [2]. However, clinical screening for silicosis still has to rely on radiological examinations and the assessment of pulmonary function abnormalities, which can only be identified in the advanced stages of the disease.

Funding: this research was supported by the "precision medicine" projects under the national key research and development program of China (grant No. 2016YFC0900605 entitled "Cohort study on health effects of natural population in Beijing Tianjin Hebei," grant manager: Prof. Juxiang Yuan), by Hebei Medical Science Research Foundation (grant No. 20190108 entitled "Screening of biomarkers for pneumoconiosis," grant manager: Ying Zhu, Ph.D.), by the Science and Technology Foundation of Tangshan (grant No. 18130206a entitled "Screening of biomarkers for early diagnosis of pneumoconiosis by iTRAQ," grant manager: Ying Zhu, Ph.D.), and by the Postgraduate Innovation Foundation of North China University of Science and Technology (grant No. 2017B20 entitled "Screening of biomarkers for pneumoconiosis," grant manager: Ying Zhu, Ph.D.).

Received: April 16, 2020. Accepted: November 15, 2020.

Corresponding author: Xiang Ju Yuan, North China University of Science and Technology, School of Public Health, 21 Bohai Road, Caofeidian County, Tangshan City, Hebei Province 063210, China (e-mail: yuanjx@ncst.edu.cn). 
The identification of accurate and reliable biomarkers would enable an earlier detection of the condition before the irreversible changes that can be detected by radiology occur in the lungs [3]. Most studies have utilized clinical patient serum to determine whether certain cytokines are appropriate biomarkers $[3,4]$. Few researchers have used proteomics to screen for differentially expressed proteins, followed by testing with serum samples to assess their diagnostic value for silicosis. The authors of this article created a rat model that closely approximates the exposure and development of silicosis in humans. Isobaric tags for relative and absolute quantitation (iTRAQ) technologies were used to identify the proteins differentially expressed in activated rat lung tissues. It was revealed that 20 upregulated and 8 downregulated proteins exhibited a $\geq 1.5$-fold change relative to the controls. It was then found that the protein tyrosine phosphatase non-receptor type 2 (PTPN2), factor B (complement factor B [CFB]), and vaccinia-related kinase 1 (VRK1) concentrations in silicotic rats and $\mathrm{SiO}_{2}$-stimulated mouse lung epithelial cells (MLE-12) were significantly higher than in the control groups [5].

Generally, PTPN2 is an intracellular tyrosine phosphatase which has a nuclear localization sequence. The authors' previous work demonstrated that the inhibition of epithelial-mesenchymal transition (EMT) by PTPN2 can be achieved by dephosphorylating signal transducer and activator of transcription 3 (STAT3) [5]. Synthesized mainly by the liver and macrophages, factor $\mathrm{B}(\mathrm{CFB})$ is a single-chain glycoprotein which consists of 733 amino acid residues. It has been shown that factor $\mathrm{B}(\mathrm{CFB})$ is synthesized and released when the macrophages receive stimuli such as transforming growth factor $\beta 1$ or lipopolysaccharides [6,7]. In addition, the overexpression of VRK1 has been proven to lessen the migration of both monocytes and lamellae, changes that are accompanied by the upregulation of the Claudin-1 and epithelial-cell adhesion molecules E-cadherin, as well as the downregu- lation of the transcriptional repressors of EMT in snails, slugs, and snails-1 [8]. Although the roles of PTPN2, VRK1, and factor B (CFB) in the pathogenesis of silicosis have not been previously reported, these proteins may be key factors in the occurrence and development of silicosis.

In this study, the serum and bronchoalveolar lavage fluid (BALF) samples were collected from patients with silicosis and healthy people to verify the expression of PTPN2, VRK1, and factor B (CFB) in the lungs. The relationships between the differentially expressed proteins and lung function were analyzed, and the diagnostic value of the proteins for silicosis was determined. The aim was to provide a theoretical basis for the study of biomarkers of silicosis.

\section{MATERIAL AND METHODS}

\section{Study participants}

In May-November 2017, 191 patients with silicosis were recruited from the Beidaihe Sanatorium of Chinese Coal Miners. Based on the diagnostic criteria for silicosis (GBZ 70-2009 "China National Occupational Health Standard"), all patients were diagnosed and phased, and underwent whole-lung lavage (WLL) therapy. In addition, 200 healthy miners were recruited from the Dongpang and Gequan Coal Mines of JIZHONG Energy Group Co., Ltd. The general health questionnaires were completed by the participants, and routine medical examinations were conducted. The exclusion criteria were applied to all participants with autoimmune diseases, cardiovascular diseases, hematological malignancies and neoplasms. This study was an experiment involving humans following the ethical guidelines of the World Medical Association (the Declaration of Helsinki), and the prior informed consent of the participants was obtained. The whole study was approved by the Ethics Committee of the North China University of Science and Technology, Tangshan, China (No. 2018021). 
Given that the BALF of healthy people cannot be collected, the authors collected BALF samples from 12 coal miners who had underwent WLL therapy in the Beidaihe Sanatorium but were not diagnosed with pneumoconiosis. These 12 miners were designated as the observation group. The authors also collected lavage fluid samples from 20 patients with silicosis in stage I, 12 patients in stage II, and 12 patients in stage III.

\section{Definition of silicosis severity}

The diagnosis of silicosis was made as per the 2000 International Labour Organization classification, in combination with the characteristic clinical and high-quality X-ray examination results [9] for diagnostic criteria of pneumoconiosis. The criteria describe stages 0 , I, II, and III as no disease, mild, moderate, and severe disease, respectively. Stage 0 for observation subjects refers to the radiological findings on X-ray that cannot be identified as stage I but require follow-up. The results of the diagnosis for each worker were recorded.

\section{Sample size}

When the estimated sensitivity is close to $50 \%$, the following formula can be used [10]:

$$
\mathrm{n}=(\mathrm{Z} \alpha / \delta) *(1-\mathrm{p}) * \mathrm{p}
$$

where:

$\mathrm{n}$ - is the required sample size and $\mathrm{Z} \alpha$ is the $\mathrm{Z}$ value when the cumulative probability in the normal distribution is equal to $\alpha / 2$, such as $Z 0.05 / 2=1.96$ or $Z 0.01 / 2=2.58$;

$\delta$ - is the allowable error, generally set at $0.05-0.10$;

$\mathrm{p}-$ is the sensitivity or specificity of the screening method to be evaluated.

Generally, sensitivity is used to estimate the sample size needed by the case group and specificity is used to estimate the sample size needed by the control group. The authors estimated sensitivity as $70 \%$ and specificity as $70 \%$, with $\alpha=0.05, \delta=0.08$. Therefore, $\mathrm{n}=(1.96 / 0.08) *(1-0.7)$

$* 0.7=126$, which implied that $>126$ samples had to be collected in each group.

\section{Sample collection}

For all participants, blood samples were taken in the morning after $8 \mathrm{~h}$ of fasting, by means of a vacutainer tube punctured with an IV. The anticoagulant-free $5 \mathrm{ml}$ tubes were centrifuged at $1500 \mathrm{rpm}$ for $10 \mathrm{~min}$ at a temperature of $20^{\circ} \mathrm{C}$, and serum was stored at a temperature of $-80^{\circ} \mathrm{C}$ for the subsequent enzyme-linked immunosorbent assay (ELISA) analysis.

The BALF samples of silicosis patients were centrifuged in a $50 \mathrm{ml}$ centrifuge tube at a temperature of $4^{\circ} \mathrm{C}$ for $10 \mathrm{~min}$ at $1800 \mathrm{rpm}$. The supernatants were stored at a temperature of $-80^{\circ} \mathrm{C}$ for western blot analysis.

\section{Occupational dust exposure}

A standard questionnaire about their work experience has been filled out by all participants. Every aspect of the participant's working life was factored in.

\section{Pulmonary function tests}

The pulmonary function of each participant was measured with a spirometer (Spirostik Complete, Geratherm, Germany). Flow-volume curves were plotted for forced vital capacity (FVC), forced expiratory volume in $1 \mathrm{~s}\left(\mathrm{FEV}_{1}\right)$, the ratio of $\mathrm{FEV}_{1} / \mathrm{FVC}$, maximum vital capacity $\left(\mathrm{VC}_{\max }\right)$, the ratio of $\mathrm{FEV}_{1} / \mathrm{VC}_{\max }$, the peak expiratory flow (PEF), the expiratory reserve volume (ERV), the maximum voluntary ventilation (MVV), the flow speed of expired air by $25 \%$ of $\mathrm{FVC}\left(\mathrm{FEF}_{25}\right)$, the flow speed of expired air by $50 \%$ of $\mathrm{FVC}\left(\mathrm{FEF}_{50}\right)$, and the flow speed of expired air by $75 \%$ of $\mathrm{FVC}\left(\mathrm{FEF}_{75}\right)$.

\section{Western blot analysis}

The quantification of total protein levels was performed using a Bradford assay (PC0020; Solarbio, Beijing, China) 
as described earlier. The proteolysates (20 $\mu \mathrm{g} /$ line) or BALF ( $20 \mu \mathrm{l} /$ /ine) were isolated via SDS-PAGE on a $13 \%$ gel and transferred to polyvinylidene fluoride (PVDF) membranes by electrophoresis. A 5\% skimmed dry milk blocking membrane was incubated with factor B (CFB) (GTX103570; GeneTex, Irvine, CA, USA), primary antibodies against PTPN2 (DF6629; Affinity Biosciences, Cincinnati, OH, USA), VRK1 (A7745; ABclonal Biotech, Boston, USA) overnight at a temperature of $4^{\circ} \mathrm{C}$. The membranes were incubated with peroxidase-labeled secondary antibody (074-1506/074-1806; Kirkegaard and Perry Laboratories, Shanghai, China). The ECL ${ }^{\mathrm{Tм}}$ Prime Western Blotting assay reagent (RPN2232; GE Healthcare, Pittsburgh, USA) was utilized for the visualization of protein strips.

\section{The ELISA analysis}

Human serum samples were collected. Based on the manufacturer's instructions, the levels of PTPN2, VRK1, and factor $\mathrm{B}(\mathrm{CFB})$ in the specimens were identified with ELISA kits (MeiBiao Biological Technology Co., Ltd., Jiangsu, China).

\section{The receiver operating characteristic (ROC) curve analysis}

The ROC curve analysis of the serum protein levels was then conducted to determine the threshold, area under the curve (AUC), sensitivity, and specificity of the serum proteins between the patients and the controls, in order to derive the optimum diagnostic accuracy for each protein.

\section{Statistical analysis}

An independent sample t-test was adopted for comparison between the 2 groups. The 1-way analysis of variance (ANOVA) was followed by a post-hoc analysis using Bonferroni's test for comparisons between multiple independent groups. The $\chi^{2}$ test, ANOVA, and conditional effect plots were performed to compare the outcomes of the groups, and multivariate logistic regression was ap- plied to evaluate the relationship between differential proteins, silicosis, and pulmonary function. Values were expressed as $\mathrm{M} \pm \mathrm{SD}$, with $\mathrm{p}$-values $<0.05$ considered statistically significant.

\section{RESULTS}

\section{Expression levels of 3 proteins in the BALF samples of patients with silicosis}

Twelve observational patients and 44 patients with silicosis were recruited, and human BALF was collected. Then, the levels of PTPN2, VRK1, and factor B (CFB) in the supernatants were determined using the western blot analysis. As shown in Figure 1, the expression levels of PTPN2, VRK1, and factor B (CFB) in the BALF samples obtained from the patients with silicosis were clearly and significantly elevated. In addition, the authors analyzed the impact of smoking pack year and dust exposure years on the PTPN2, VRK1, and factor B (CFB) proteins expression in the BALF specimens. As shown in Table 1, Spearman's correlation analysis showed that smoking pack year and dust exposure years had no correlation with the expression of the 3 factors in the BALF specimens ( $p>0.05)$.

\section{Validation of increased proteins in the serum by ELISA}

The authors collected serum samples from 191 patients with silicosis and from 200 healthy coal miners. No significant differences in age, gender, dust exposure, or smoking and drinking habits were found to occur between the patients and healthy people ( $p>0.05)$. The relevant demographic information is listed in Table 2.

The authors then validated the PTPN2, VRK1, and factor $\mathrm{B}$ (CFB) expression levels in the serum of the patients with silicosis and healthy subjects. As shown in Figure 2a-c, the expression levels of PTPN2, VRK1, and factor $\mathrm{B}(\mathrm{CFB})$ were significantly higher in the patients with silicosis. The expression levels of serum PTPN2, VRK1, and factor B (CFB) in the patients with silicosis were $2932.2 \pm 154.2,317.9 \pm 15.1$, and $1603.6 \pm 122.7 \mathrm{pg} / \mathrm{ml}$, 

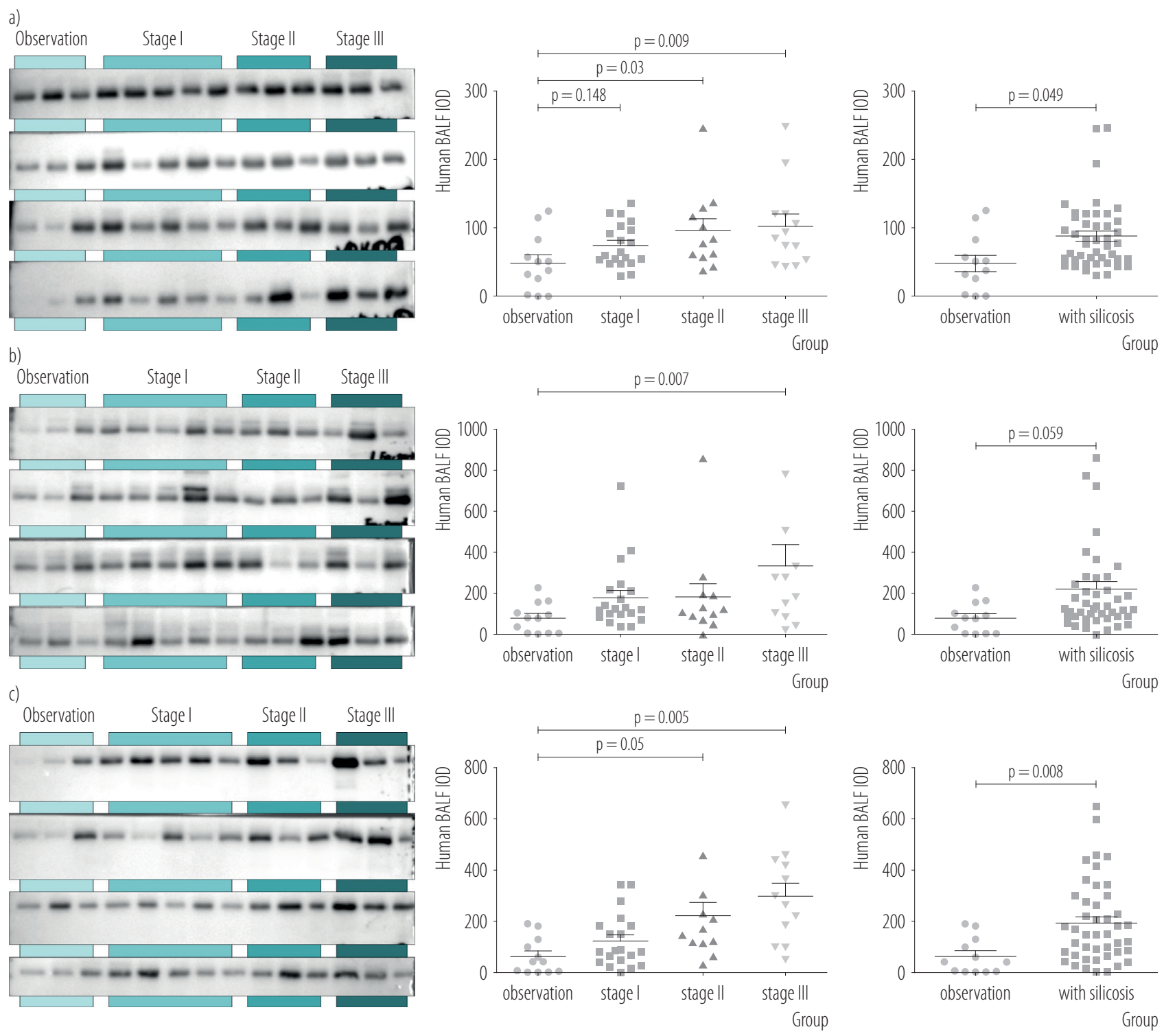

The first 3 lanes of each band represent the observational patient group, the fourth-eighth lanes are the first-stage patient group, the ninth-11th lanes are the second-stage patient group, and the 12-14th lanes are the third-stage patient group.

The authors performed statistical analysis by stage, and by patient vs. observational subject. Statistical analysis was performed using a t-test with SPSS20.

Figure 1. The western blot analysis and corresponding densitometry data of the expression levels of a) protein tyrosine phosphatase non-receptor type (PTPN2), b) factor B (complement factor B [CFB]), and c) vaccinia-related kinase 1 (VRK1), in the bronchoalveolar lavage fluid (BALF) of patients with silicosis $(\mathrm{N}=191)$ from the Beidaihe Sanatorium of Chinese Coal Miners, and healthy miners ( $=200)$ from the Dongpang and Gequan Coal Mines of JIZHONG Energy Group Co., Ltd., May-November 2017, China

respectively, all of which were higher than the levels recorded in the control group $(1376.0 \pm 43.4 \mathrm{pg} / \mathrm{ml}, 203.8 \pm 10.8 \mathrm{pg} / \mathrm{ml}$, and $868.1 \pm 31.9 \mathrm{pg} / \mathrm{ml})(\mathrm{p}<0.01)$. Equally, the authors analyzed the impact of smoking pack year and dust exposure years on the PTPN2, VRK1, and factor B (CFB) proteins expression in the serum specimens. As shown 
Table 1. The correlation between smoking pack year, dust exposure years and the expression levels of protein tyrosine phosphatase non-receptor type 2 (PTPN2), vaccinia-related kinase 1 (VRK1), and factor B (complement factor B [CFB]) in the bronchoalveolar lavage fluid (BALF) and serum samples obtained from patients with silicosis ( $\mathrm{N}=191)$ and healthy miners $(\mathrm{N}=200)$, May-November 2017, China

\begin{tabular}{lccc}
\hline \multicolumn{1}{c}{ Factor } & PTPN2 & VRK1 & Factor B (CFB) \\
\hline BALF & & & \\
dust exposure years & & & \\
r & 0.048 & 0.063 & 0.107 \\
p & 0.724 & 0.646 & 0.366 \\
smoking pack year & & & \\
r & 0.028 & -0.053 & 0.006 \\
p & 0.838 & 0.696 & 0.958 \\
Serum & & & \\
dust exposure years & & & 0.000 \\
r & 0.042 & 0.068 & 0.993 \\
p & 0.403 & 0.179 & \\
smoking pack year & & & 0.056 \\
r & 0.028 & 0.037 & 0.265 \\
p & 0.587 & 0.470 & \\
\hline
\end{tabular}

Table 2. Clinical data of patients with silicosis $(\mathrm{N}=191)$ from the Beidaihe Sanatorium of Chinese Coal Miners, and healthy miners (N = 200) from the Dongpang and Gequan Coal Mines of JIZHONG Energy Group Co., Ltd., May-November 2017, China

\begin{tabular}{|c|c|c|c|c|c|}
\hline \multirow{2}{*}{ Variable } & \multicolumn{4}{|c|}{$\begin{array}{l}\text { Participants } \\
(\mathrm{N}=391)\end{array}$} & \multirow{2}{*}{$\mathrm{p}$} \\
\hline & $\begin{array}{l}\text { control group } \\
(\mathrm{N}=200)\end{array}$ & $\begin{array}{l}\text { stage I } \\
(\mathrm{N}=96)\end{array}$ & $\begin{array}{c}\text { stage II } \\
(\mathrm{N}=47)\end{array}$ & $\begin{array}{l}\text { stage III } \\
(\mathrm{N}=48)\end{array}$ & \\
\hline Sex (male) $[\mathrm{n}(\%)]$ & $200(100)$ & $96(100)$ & $47(100)$ & $48(100)$ & - \\
\hline Age [years] $(\mathrm{M} \pm \mathrm{SD})$ & $48.91 \pm 6.87$ & $48.65 \pm 6.58$ & $50.70 \pm 5.55$ & $49.94 \pm 6.39$ & 0.393 \\
\hline Dust exposure time [years] $(\mathrm{M} \pm \mathrm{SD})$ & $18.28 \pm 6.71$ & $17.19 \pm 9.59$ & $20.81 \pm 7.09$ & $21.15 \pm 8.06$ & 0.315 \\
\hline Types of dust exposure [n (\%)] & & & & & 0.748 \\
\hline silica dust & $99(49.5)$ & $42(43.8)$ & $22(46.8)$ & $25(52.1)$ & \\
\hline mix dust & $101(50.5)$ & $54(56.2)$ & $25(53.2)$ & $23(47.9)$ & \\
\hline Smoking $[\mathrm{n}(\%)]$ & & & & & 0.619 \\
\hline yes & $153(76.5)$ & $74(77.1)$ & $39(83.0)$ & $40(83.3)$ & \\
\hline no & $47(23.5)$ & $22(22.9)$ & $8(17.0)$ & $8(16.7)$ & \\
\hline Drinking $[\mathrm{n}(\%)]$ & & & & & 0.935 \\
\hline yes & $142(71.0)$ & $70(72.9)$ & $33(70.2)$ & $36(75.0)$ & \\
\hline no & $58(29.0)$ & $26(27.1)$ & $14(29.8)$ & $12(25.0)$ & \\
\hline
\end{tabular}

Stage I - mild disease; stage II - moderate disease; stage III - severe disease. 

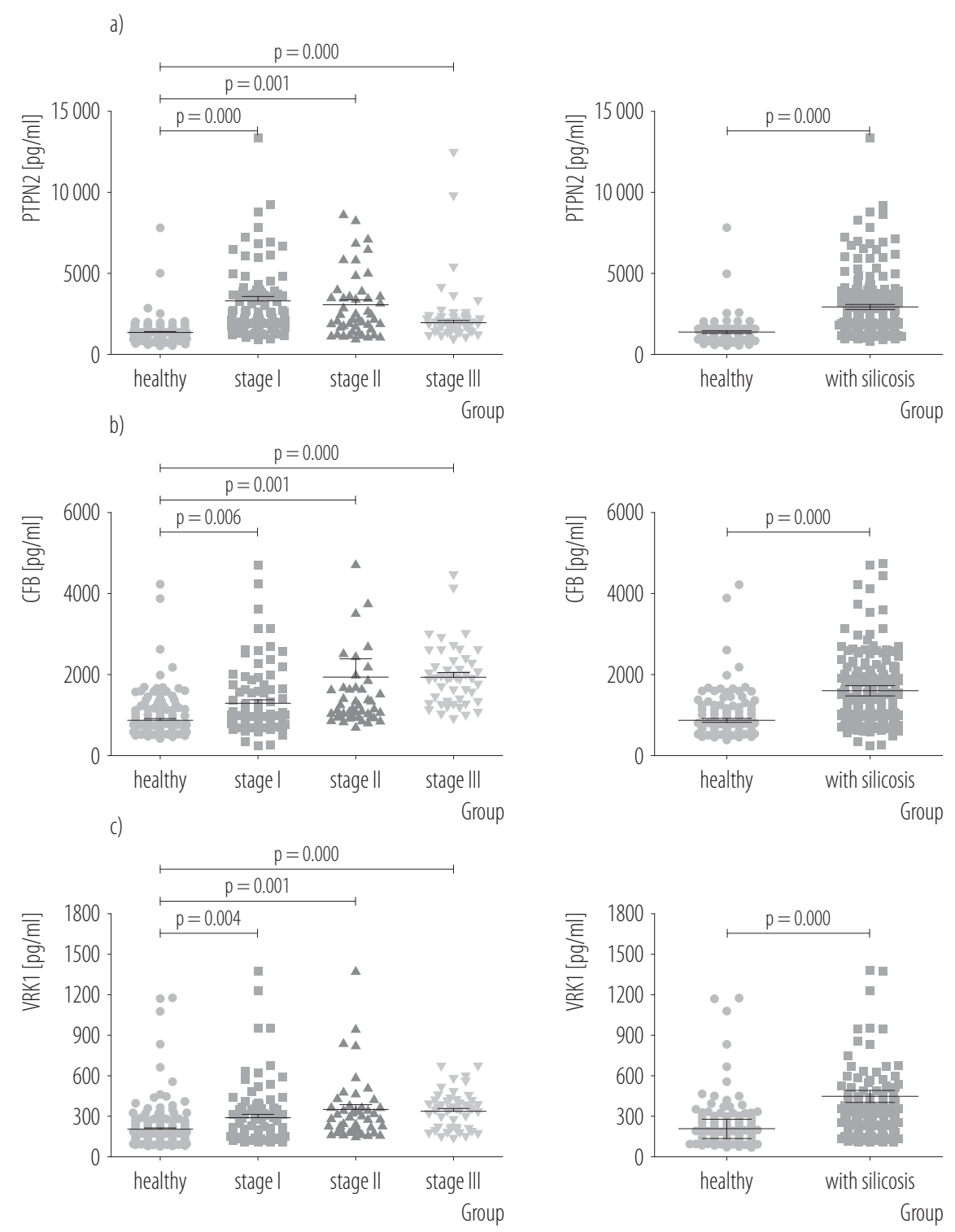

The expression levels of PTPN2 in the patient group are significantly higher than in the control group $(\mathrm{p}<0.01)$.

The expression levels of factor B (CFB) in the patient group are significantly higher than in the control group $(\mathrm{p}<0.01)$.

The expression levels of VRK1 in the patient group are significantly higher than in the control group $(\mathrm{p}<0.01)$.

Stage I - mild disease; stage II - moderate disease; stage III - severe disease.

Figure 2. The a) protein tyrosine phosphatase non-receptor type (PTPN2), b) factor B (complement factor B [CFB]), and c) vaccinia-related kinase 1 (VRK1) expression levels in the serum of patients with silicosis $(\mathrm{N}=191)$ from the Beidaihe Sanatorium of Chinese Coal Miners, and healthy miners $(\mathrm{N}=200)$ from the Dongpang and Gequan Coal Mines of JIZHONG Energy Group Co., Ltd., May-November 2017, China

in Table 1, Spearman's correlation analysis showed that smoking pack year and dust exposure years had no correlation with the expression of the 3 factors in the serum specimens $(p>0.05)$. In addition, the correlation between the expression levels of the 3 protein factors in the serum and BALF samples was analyzed. As shown in Table 3, 
Table 3. The correlation of expression of protein tyrosine phosphatase non-receptor type 2 (PTPN2), vaccinia-related kinase 1 (VRK1) and factor B (complement factor B [CFB]) in the serum and bronchoalveolar lavage fluid (BALF) samples obtained from patients with silicosis $(\mathrm{N}=191)$ and healthy people $(\mathrm{N}=200)$, May-November 2017, China

\begin{tabular}{lccc}
\hline Parameter & PTPN2 & VRK1 & Factor B (CFB) \\
\hline $\mathrm{r}$ & $0.307^{*}$ & $0.358^{* *}$ & $0.346^{* *}$ \\
$\mathrm{p}$ & 0.021 & 0.007 & 0.003 \\
\hline
\end{tabular}

$* \mathrm{p}<0.05 ; * \mathrm{p}<0.01$

Spearman's correlation analysis showed that the level of the 3 factors in BALF correlated with that in the serum $(\mathrm{p}<0.05$ or 0.01$)$.

\section{Pulmonary function of healthy workers and patients with silicosis}

In addition to ERV, the other lung function parameters of the patients with stage III silicosis were significantly lower than in the healthy group $(\mathrm{p}<0.05)$; in addition to ERV and PEF, the other lung function parameters of the patients with stage II silicosis were significantly lower than in the healthy group $(\mathrm{p}<0.05)$; while in the patients with stage I silicosis, the lung function parameters, except ERV, PEF, and $\mathrm{FEF}_{75}$, were significantly lower than in the healthy group $(\mathrm{p}<0.05)$. The results are shown in Table 4.

\section{Correlation between lung function and the differentially expressed proteins}

The correlation between lung function parameters and the expression of PTPN2, VRK1, and factor B (CFB) was evaluated in the samples of healthy people and patients with silicosis. Spearman's correlation analysis showed that only $\mathrm{FEV}_{1}(\mathrm{~L})$ was correlated with the expression of PTPN2 ( $<<0.05)$, and the other lung function parameters were not correlated with the 3 factors $(p>0.05)$. The results are shown in Table 5.

\section{The ROC curve analysis of PTPN2,} VRK1, and factor $B$ (CFB) in the serum of patients with silicosis and healthy miners

The ROC curve analysis was performed to better assess the clinical utility of each protein for silicosis prediction. The AUC measurements generated from single detection events were $>0.744$, with the highest AUC concerning PTPN2 (0.858) (Figure 3a). As shown in Table 6, when the cut-off values of $1836 \mathrm{pg} / \mathrm{ml}, 284 \mathrm{pg} / \mathrm{ml}$, and $868 \mathrm{pg} / \mathrm{ml}$ were chosen for PTPN2, VRK1, and factor B (CFB), the sensitivity and specificity for the patients were $70.68 \%$ and $91.04 \%$ for PTPN2, $49.74 \%$ and $86.07 \%$ for VRK1, and $81.68 \%$ and $74.63 \%$ for factor B (CFB), respectively. In addition, the ROC analysis was performed on the expression of PTPN2, VRK1, and factor B (CFB) in the BALF samples for comparison with the AUCs in the serum. The results are shown in Table 7. At the same time, the authors also performed the ROC analysis on lung function parameters. The results showed that the best sample for an early diagnosis of silicosis was serum.

The diagnosis was performed using a combination of 2 and 3 proteins, and the results are shown in Table 4 and Figure $3 \mathrm{~b}$. The combined diagnosis with factor B (CFB) and PTPN2 produced the highest AUC (0.906), the single diagnosis with PTPN2 gave the highest specificity (91.04\%), and the combined diagnosis with PTPN2 and factor B (CFB) gave the highest sensitivity (86.91\%). With regard to the test economy and practicality of operation, a combination of factor B (CFB) and PTPN2 was optimum for AUC, sensitivity, and specificity.

\section{DISCUSSION}

The many uses of patient serum include the early detection, diagnosis, risk prediction, and prognosis of the disease, and the monitoring of therapeutic response [11,12]. However, when using clinical patient serum samples for screening, individual nuances can affect the expression of serum proteins and even the serum proteome. The use 
Table 4. The pulmonary function of patients with silicosis $(\mathrm{N}=191)$ from the Beidaihe Sanatorium of Chinese Coal Miners, and healthy miners $(\mathrm{N}=200)$ from the Dongpang and Gequan Coal Mines of JIZHONG Energy Group Co., Ltd., May-November 2017, China

\begin{tabular}{|c|c|c|c|c|}
\hline \multirow{2}{*}{ Parameter } & \multicolumn{4}{|c|}{$\begin{array}{c}\text { Participants } \\
(\mathrm{N}=391) \\
(\mathrm{M} \pm \mathrm{SD})\end{array}$} \\
\hline & $\begin{array}{l}\text { control group } \\
(\mathrm{N}=200)\end{array}$ & $\begin{array}{l}\text { stage I } \\
(\mathrm{N}=96)\end{array}$ & $\begin{array}{l}\text { stage II } \\
(\mathrm{N}=47)\end{array}$ & $\begin{array}{l}\text { stage III } \\
(\mathrm{N}=48)\end{array}$ \\
\hline $\mathrm{FEV}_{1} / \mathrm{FVC}[\%]$ & $100.19 \pm 11.39$ & $78.10 \pm 10.81^{\mathrm{a}}$ & $76.35 \pm 12.24^{a}$ & $69.68 \pm 14.54^{\mathrm{a}, \mathrm{b}, \mathrm{c}}$ \\
\hline $\mathrm{FEV}_{1} / \mathrm{VC}_{\max }[\%]$ & $98.99 \pm 11.43$ & $95.28 \pm 13.95^{\mathrm{a}}$ & $91.84 \pm 14.37^{\mathrm{a}}$ & $80.10 \pm 16.17^{\mathrm{a}, \mathrm{b}, \mathrm{c}}$ \\
\hline $\mathrm{PEF}[1 / \mathrm{s}]$ & $62.23 \pm 17.77$ & $59.24 \pm 25.71$ & $54.81 \pm 21.65$ & $38.24 \pm 18.11^{\mathrm{a}, \mathrm{b}, \mathrm{c}}$ \\
\hline ERV [1] & $81.09 \pm 10.79$ & $80.97 \pm 36.06$ & $79.30 \pm 37.35$ & $80.37 \pm 44.71$ \\
\hline MVV [1/min] & $82.73 \pm 18.80$ & $76.00 \pm 20.60^{\mathrm{a}}$ & $66.15 \pm 20.13^{\mathrm{a}, \mathrm{b}}$ & $46.62 \pm 16.30^{\mathrm{a}, \mathrm{b}, \mathrm{c}}$ \\
\hline $\mathrm{VC}_{\text {max }}[1]$ & $98.24 \pm 22.20$ & $84.48 \pm 12.25^{\mathrm{a}}$ & $81.62 \pm 16.06^{\mathrm{a}}$ & $66.59 \pm 15.96^{\mathrm{a}, \mathrm{b}, \mathrm{c}}$ \\
\hline $\mathrm{FEV}_{1}[1]$ & $97.77 \pm 22.43$ & $80.95 \pm 16.84^{\mathrm{a}}$ & $75.34 \pm 18.75^{\mathrm{a}}$ & $55.04 \pm 19.82^{\mathrm{a}, \mathrm{b}, \mathrm{c}}$ \\
\hline $\mathrm{FVC}[1]$ & $102.39 \pm 23.34$ & $83.93 \pm 13.58^{\mathrm{a}}$ & $80.70 \pm 16.66^{\mathrm{a}}$ & $63.53 \pm 18.63^{\mathrm{a}, \mathrm{b}, \mathrm{c}}$ \\
\hline $\mathrm{FEF}_{75}[1 / \mathrm{s}]$ & $67.27 \pm 20.61$ & $67.74 \pm 29.41$ & $55.03 \pm 27.46^{\mathrm{a}}$ & $37.85 \pm 17.54^{a, b, c}$ \\
\hline $\mathrm{FEF}_{50}[1 / \mathrm{s}]$ & $88.36 \pm 26.95$ & $70.41 \pm 30.32^{\mathrm{a}}$ & $60.95 \pm 26.06^{\mathrm{a}}$ & $35.33 \pm 19.65^{\mathrm{a}, \mathrm{b}, \mathrm{c}}$ \\
\hline $\mathrm{FEF}_{25}[\mathrm{l} / \mathrm{s}]$ & $96.74 \pm 41.79$ & $61.74 \pm 25.77^{\mathrm{a}}$ & $56.94 \pm 23.23^{\mathrm{a}}$ & $37.03 \pm 18.90^{\mathrm{a}, \mathrm{b}, \mathrm{c}}$ \\
\hline
\end{tabular}

FVC - flow-volume curves were plotted for forced vital capacity; $\mathrm{FEV}_{1}$ - forced expiratory volume in $1 \mathrm{~s} ; \mathrm{FEV}_{1} / \mathrm{FVC}$ - the ratio of forced expiratory volume in $1 \mathrm{~s}$ to forced vital capacity; $\mathrm{VC}_{\text {max }}$ - maximum vital capacity; $\mathrm{FEV}_{1} / \mathrm{VC}_{\max }$ - the ratio of forced expiratory volume in $1 \mathrm{~s}$ to maximum vital

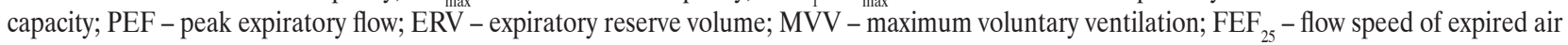
by $25 \%$ of forced vital capacity; $\mathrm{FEF}_{50}$ - flow speed of expired air by $50 \%$ of forced vital capacity; $\mathrm{FEF}_{75}-$ flow speed of expired air by $75 \%$ of forced vital capacity.

${ }^{a}$ Compared with the healthy group $(\mathrm{p}<0.05) ;{ }^{\mathrm{b}}$ compared with stage I silicosis patients $(\mathrm{p}<0.05)$; $^{\mathrm{c}}$ compared with stage II silicosis patients $(\mathrm{p}<0.05)$.

Table 5. The correlation between lung function and the differentially expressed proteins in the serum samples obtained from patients with silicosis $(\mathrm{N}=191)$ from the Beidaihe Sanatorium of Chinese Coal Miners, and healthy miners $(\mathrm{N}=200)$ from the Dongpang and Gequan Coal Mines of JIZHONG Energy Group Co., Ltd., May-November 2017, China

\begin{tabular}{|c|c|c|c|c|c|c|}
\hline \multirow{3}{*}{ Parameter } & \multicolumn{6}{|c|}{$\begin{array}{l}\text { Participants } \\
(\mathrm{N}=391)\end{array}$} \\
\hline & \multicolumn{3}{|c|}{$\begin{array}{l}\text { control group } \\
(\mathrm{N}=200)\end{array}$} & \multicolumn{3}{|c|}{$\begin{array}{l}\text { patients with silicosis } \\
(\mathrm{N}=191)\end{array}$} \\
\hline & PTPN2 & VRK1 & factor $\mathrm{B}(\mathrm{CFB})$ & PTPN2 & VRK1 & factor $\mathrm{B}(\mathrm{CFB})$ \\
\hline \multicolumn{7}{|l|}{$\mathrm{FEV}_{1} / \mathrm{FVC}[\%]$} \\
\hline $\mathrm{r}$ & -0.052 & -0.022 & -0.116 & -0.001 & -0.011 & 0.029 \\
\hline $\mathrm{p}$ & 0.506 & 0.781 & 0.138 & 0.992 & 0.890 & 0.713 \\
\hline \multicolumn{7}{|l|}{$\mathrm{FEV}_{1} / \mathrm{VC}_{\max }[\%]$} \\
\hline $\mathrm{r}$ & -0.006 & -0.058 & -0.077 & 0.000 & -0.053 & -0.056 \\
\hline $\mathrm{p}$ & 0.942 & 0.455 & 0.323 & 0.997 & 0.503 & 0.483 \\
\hline
\end{tabular}


Table 5. The correlation between lung function and the differentially expressed proteins in the serum samples obtained from patients with silicosis $(\mathrm{N}=191)$ from the Beidaihe Sanatorium of Chinese Coal Miners, and healthy miners $(\mathrm{N}=200)$ from the Dongpang and Gequan Coal Mines of JIZHONG Energy Group Co., Ltd., May-November 2017, China - cont.

\begin{tabular}{|c|c|c|c|c|c|c|}
\hline \multirow{3}{*}{ Parameter } & \multicolumn{6}{|c|}{$\begin{array}{l}\text { Participants } \\
(\mathrm{N}=391)\end{array}$} \\
\hline & \multicolumn{3}{|c|}{$\begin{array}{l}\text { control group } \\
(\mathrm{N}=200)\end{array}$} & \multicolumn{3}{|c|}{$\begin{array}{l}\text { patients with silicosis } \\
\qquad(\mathrm{N}=191)\end{array}$} \\
\hline & PTPN2 & VRK1 & factor $\mathrm{B}(\mathrm{CFB})$ & PTPN2 & VRK1 & factor $\mathrm{B}(\mathrm{CFB})$ \\
\hline \multicolumn{7}{|l|}{$\mathrm{PEF}[\mathrm{l} / \mathrm{s}]$} \\
\hline $\mathrm{r}$ & -0.150 & -0.117 & -0.082 & 0.007 & -0.024 & 0.015 \\
\hline $\mathrm{p}$ & 0.054 & 0.135 & 0.294 & 0.930 & 0.768 & 0.852 \\
\hline \multicolumn{7}{|l|}{ ERV [1] } \\
\hline $\mathrm{r}$ & -0.017 & -0.121 & 0.034 & 0.013 & -0.041 & -0.002 \\
\hline $\mathrm{p}$ & 0.868 & 0.230 & 0.735 & 0.871 & 0.610 & 0.983 \\
\hline \multicolumn{7}{|l|}{ MVV [1/min] } \\
\hline $\mathrm{r}$ & -0.027 & 0.025 & -0.036 & 0.116 & -0.117 & -0.093 \\
\hline $\mathrm{p}$ & 0.727 & 0.751 & 0.647 & 0.144 & 0.144 & 0.242 \\
\hline \multicolumn{7}{|l|}{$\mathrm{VC}_{\max }[\mathrm{l}]$} \\
\hline $\mathrm{r}$ & -0.102 & -0.014 & -0.068 & 0.143 & -0.096 & -0.052 \\
\hline $\mathrm{p}$ & 0.191 & 0.863 & 0.384 & 0.072 & 0.231 & 0.516 \\
\hline \multicolumn{7}{|l|}{$\mathrm{FEV}_{1}[1]$} \\
\hline $\mathrm{r}$ & $-0.158^{*}$ & -0.096 & -0.118 & 0.093 & -0.085 & -0.043 \\
\hline $\mathrm{p}$ & 0.043 & 0.216 & 0.129 & 0.242 & 0.284 & 0.586 \\
\hline \multicolumn{7}{|l|}{$\mathrm{FVC}[1]$} \\
\hline $\mathrm{r}$ & -0.099 & -0.015 & -0.064 & 0.136 & -0.100 & -0.059 \\
\hline $\mathrm{p}$ & 0.204 & 0.844 & 0.410 & 0.087 & 0.208 & 0.461 \\
\hline \multicolumn{7}{|l|}{$\mathrm{FEF}_{75}[\mathrm{l} / \mathrm{s}]$} \\
\hline $\mathrm{r}$ & -0.115 & -0.119 & -0.023 & 0.054 & -0.093 & -0.064 \\
\hline $\mathrm{p}$ & 0.139 & 0.128 & 0.768 & 0.501 & 0.246 & 0.423 \\
\hline \multicolumn{7}{|l|}{$\mathrm{FEF}_{50}[1 / \mathrm{s}]$} \\
\hline $\mathrm{r}$ & -0.112 & -0.098 & -0.005 & 0.090 & -0.092 & -0.059 \\
\hline $\mathrm{p}$ & 0.151 & 0.209 & 0.947 & 0.262 & 0.248 & 0.463 \\
\hline \multicolumn{7}{|l|}{$\mathrm{FEF}_{25}[\mathrm{l} / \mathrm{s}]$} \\
\hline $\mathrm{r}$ & 0.025 & 0.011 & -0.129 & 0.050 & -0.045 & -0.014 \\
\hline $\mathrm{p}$ & 0.744 & 0.885 & 0.097 & 0.528 & 0.571 & 0.864 \\
\hline
\end{tabular}

PTPN2 - protein tyrosine phosphatase non-receptor type 2; VRK1 - vaccinia-related kinase 1; CFB - complement factor B. Other abbreviations as in Table 4.

$* p<0.05$. 
Table 6. The diagnostic value of protein tyrosine phosphatase non-receptor type 2 (PTPN2), vaccinia-related kinase 1 (VRK1) and factor B (complement factor B [CFB]) for individual and combined detection in the serum of patients with silicosis $(\mathrm{N}=191)$ from the Beidaihe Sanatorium of Chinese Coal Miners, and healthy miners $(\mathrm{N}=200)$ from the Dongpang and Gequan Coal Mines of JIZHONG Energy Group Co., Ltd., May-November 2017, China

\begin{tabular}{lccccc}
\hline \multicolumn{1}{c}{ Factor } & AUC & $\begin{array}{c}\text { Sensitivity } \\
{[\%]}\end{array}$ & $\begin{array}{c}\text { Specificity } \\
{[\%]}\end{array}$ & 95\% CI & $\begin{array}{c}\text { Cut-off } \\
{[\mathrm{pg} / \mathrm{ml}]}\end{array}$ \\
\hline Factor B (CFB) & 0.814 & 81.68 & 74.63 & $0.772-0.851$ & 868 \\
PTPN2 & 0.858 & 70.68 & 91.04 & $0.819-0.891$ & 1836 \\
VRK1 & 0.744 & 49.74 & 86.07 & $0.698-0.787$ & 284 \\
Factor B (CFB) + PTPN2 & 0.907 & 86.91 & 85.07 & $0.874-0.934$ & - \\
Factor B (CFB) + VRK1 & 0.811 & 73.82 & 81.09 & $0.769-0.849$ & - \\
PTPN2 + VRK1 & 0.881 & 80.10 & 83.08 & $0.845-0.911$ & - \\
Factor B (CFB) + PTPN2 + VRK1 & 0.906 & 85.86 & 86.57 & $0.873-0.933$ & - \\
\hline
\end{tabular}

AUC - area under the curve.

Table 7. The Receiver Operating Characteristic Curve analysis of protein tyrosine phosphatase non-receptor type 2 (PTPN2), vaccinia-related kinase 1 (VRK1) and factor B (complement factor B [CFB]) in the bronchoalveolar lavage fluid (BALF) and pulmonary function parameters in patients with silicosis $(\mathrm{N}=191)$ from the Beidaihe Sanatorium of Chinese Coal Miners, and healthy miners ( $\mathrm{N}=200)$ from the Dongpang and Gequan Coal Mines of JIZHONG Energy Group Co., Ltd., May-November 2017, China

\begin{tabular}{|c|c|c|c|c|}
\hline Parameter & AUC & $\begin{array}{c}\text { Sensitivity } \\
{[\%]}\end{array}$ & $\begin{array}{c}\text { Specificity } \\
{[\%]}\end{array}$ & $95 \% \mathrm{CI}$ \\
\hline PTPN2 & 0.704 & 75.0 & 66.7 & $0.517-0.852$ \\
\hline VRK1 & 0.694 & 95.0 & 41.7 & $0.506-0.844$ \\
\hline Factor B (CFB) & 0.741 & 65.9 & 75.0 & $0.607-0.849$ \\
\hline $\mathrm{FEV}_{1} / \mathrm{FVC}[\%]$ & 0.741 & 74.8 & 67.3 & $0.603-0.767$ \\
\hline $\mathrm{FEV}_{1} / \mathrm{VC}_{\max }[\%]$ & 0.574 & 46.8 & 73.5 & $0.509-0.637$ \\
\hline $\operatorname{PEF}[1 / \mathrm{s}]$ & 0.577 & 40.3 & 86.7 & $0.512-0.640$ \\
\hline ERV [l] & 0.599 & 53.9 & 59.0 & $0.534-0.661$ \\
\hline $\mathrm{MVV}[1 / \mathrm{min}]$ & 0.608 & 41.6 & 78.9 & $0.544-0.670$ \\
\hline $\mathrm{VC}_{\max }[\mathrm{l}]$ & 0.742 & 56.6 & 87.0 & $0.682-0.796$ \\
\hline $\mathrm{FEV}_{1}[1]$ & 0.758 & 59.7 & 80.7 & $0.699-0.811$ \\
\hline $\mathrm{FVC}[1]$ & 0.714 & 78.3 & 57.8 & $0.738-0.843$ \\
\hline $\mathrm{FEF}_{75}[\mathrm{l} / \mathrm{s}]$ & 0.529 & 15.6 & 96.4 & $0.464-0.593$ \\
\hline $\mathrm{FEF}_{50}[\mathrm{l} / \mathrm{s}]$ & 0.699 & 84.4 & 26.3 & $0.637-0.756$ \\
\hline $\mathrm{FEF}_{25}[\mathrm{l} / \mathrm{s}]$ & 0.780 & 64.9 & 69.3 & $0.723-0.830$ \\
\hline
\end{tabular}

Abbreviations as in Table 4. 

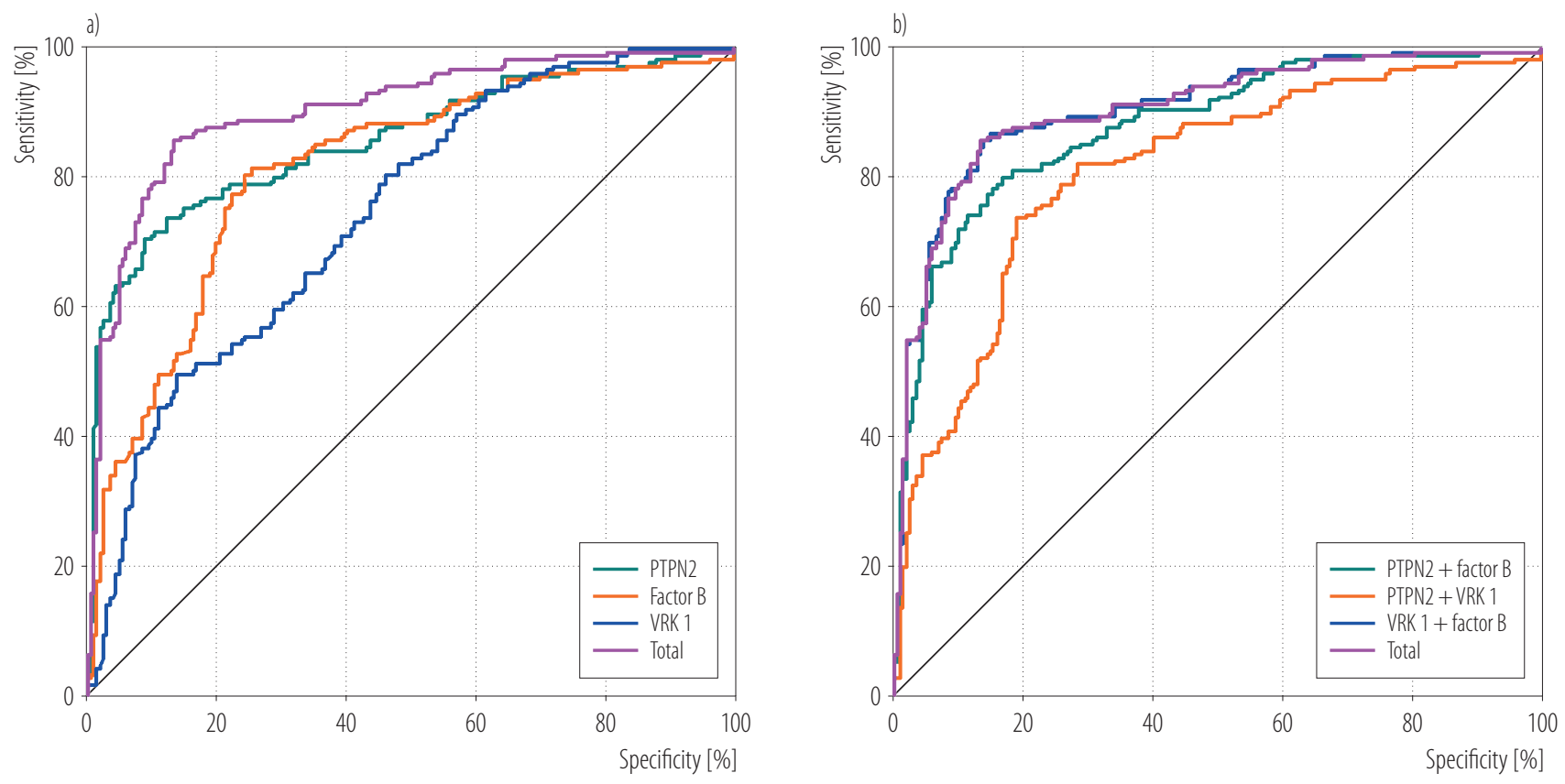

Figure 3. The receiver operating characteristic curve analysis in the serum of patients with silicosis $(\mathrm{N}=191)$ from the Beidaihe Sanatorium of Chinese Coal Miners, and healthy miners $(\mathrm{N}=200)$ from the Dongpang and Gequan Coal Mines of JIZHONG Energy Group Co., Ltd., May-November 2017, China: a) for individual and combined diagnosis with protein tyrosine phosphatase non-receptor type (PTPN2), factor B (complement factor B [CFB]), and vaccinia-related kinase 1 (VRK1), b) for combined diagnosis with 2 and 3 proteins

of animal models can reduce the impact of environmental and behavioral differences on the proteome through strictly controlled experiments, facilitating the assessment of changes in the proteome that may be caused by the disease, and the validation of such changes based on an assessment scale for clinical samples.

The authors used iTRAQ to quantitatively identify the increase in proteins in the lung tissue of the activated rats. The ensuant rat model closely approximates the exposure and development of silicosis in humans [5]. A total of 471 proteins were differentially expressed in the silicosis group compared with the controls. It was revealed that 20 upregulated and 8 downregulated proteins exhibited a $\geq 1.5$-fold change relative to the controls. The differential expression of PTPN2, factor B (CFB), and VRK1 were confirmed in the model animals and lung epithelial cells [5]. So, in this study, the serum and BALF samples were collected from both patients with silicosis and healthy people to verify the expression of the 3 differential proteins. The diagnostic value of the differentially expressed proteins for silicosis was also judged.

A number of protein tyrosine kinase targets can be dephosphorylated by PTPN2. The STAT family transcription factors are translocated into the nucleus after activation, and can then be dephosphorylated and inactivated as PTPN2 substrates [13]. Various investigations have demonstrated that the family members of STAT take an essential role in the generation and development of pulmonary fibrosis [14]. Besides, the aberrant activation of the STAT3 signaling pathway is involved in the occurrence of EMT, which is inhibited by lower IL-6 concentration following STAT3 dephosphorylation. [15]. The authors' previous research showed that PTPN2 could inhibit EMT by dephosphorylating STAT3 in silicosis fibrosis [5]. In this study, the data revealed that the concentrations of the serum factors, factor B (CFB) 
and VRK1, correlated with the extent of diffuse fibrosis in the patients with silicosis, while the serum PTPN2 concentrations were slightly decreased in the patients with stage III silicosis.

It is possible that PTPN2 has a protective role during the occurrence and development of silicosis fibrosis, and the protective mechanism is related to the inhibition of EMT. Therefore, the serum PTPN2 levels are higher in the middle and early stages of the disease, while the protective effect of PTPN2 decreases in the later stages of silicosis fibrosis, and the serum content of PTPN2 decreases slightly in the patients with stage III silicosis. This result also confirmed the authors' experimental results in rats.

The ROC curve analysis showed that the AUC was the largest for PTPN2, indicating that it is more accurate than factor $\mathrm{B}(\mathrm{CFB})$ and VRK1 for the diagnosis of silicosis. The ROC curves for the combined diagnosis with all 3 factors, and with factor B (CFB) and PTPN2, almost coincide, and the AUC, sensitivity, and specificity show no significant differences between the 2 diagnostic methods - both are more accurate than the single factor diagnoses. The results show that VRK1 has little diagnostic value for silicosis, although its AUC was also $>0.7$, and its specificity was $86.07 \%$. Therefore, factor B (CFB) and PTPN2 were found to be the best combination when measuring AUC, sensitivity, and specificity for silicosis. When analyzing the relationships between PTPN2, factor B (CFB), and VRK1 concentrations and pulmonary function, it was found that the higher serum PTPN2 and factor B (CFB) concentrations significantly and negatively correlated with $\mathrm{FEV}_{1} / \mathrm{FVC}, \mathrm{VC}_{\max }, \mathrm{FEV}_{1}$, and FVC, suggesting that the high levels of PTPN2 and factor $\mathrm{B}(\mathrm{CFB})$ are associated with decreased pulmonary ventilation function and restrictive ventilatory impairment in patients with silicosis [16,17].

\section{CONCLUSIONS}

In summary, the authors found 3 potential classes of predictive biomarkers for silicosis. The best diagnostic combination was found to be that of factor $\mathrm{B}(\mathrm{CFB})$ and PTPN2. The AUC, sensitivity, and specificity for the combined diagnosis using factor B (CFB) and PTPN2 were: $0.907,86.91 \%$ and $85.07 \%$, respectively, for factor B (CFB) and PTPN2. There are some limitations of this study. First of all, the authors were not able to evaluate the dynamic changes in silicosis progression by continuously monitoring biomarker concentrations in each patient. Second, a larger sample size is needed to further clarify the diagnostic performance of the 3 markers in silicosis screening.

\section{ACKNOWLEDGMENTS}

The authors would like to thank the Edanz Group for editing the draft of this manuscript.

\section{REFERENCES}

1. Zhao JQ, Li JG, Zhao CX. Prevalence of pneumoconiosis among young adults aged 24-44 years in a heavily industrialized province of China. J Occup Health. 2019;61(1):73-81, https://doi.org/10.1002/1348-9585.12029.

2. Yen CM, Lin CL, Lin MC, Chen HY, Lu NH, Kao CH. Pneumoconiosis increases the risk of congestive heart failure: A nationwide population-based cohort study. Medicine (Baltimore). 2016;95(25):e3972, https://doi.org/10.1097/MD. 0000000000003972.

3. Jong SL, Jae HS, Kyung ML, Ju-Hwan H, Jin EB, Ji Hong K, et al. Serum levels of TGF-beta1 and MCP-1 as biomarkers for progressive coal workers' pneumoconiosis in retired coal workers: a three-year follow-up study. Industrial Health. 2014;52(2):129-36, https://doi.org/10.2486/indhealth. 2013-0112.

4. Changjiang X, Na W, Xue L, Meihua Q, Xuqin D, Qiao Y. Serum concentrations of Krebs von den Lungen-6, surfactant protein $\mathrm{D}$, and matrix metalloproteinase-2 as diagnostic biomarkers in patients with asbestosis and silicosis: a case-control study. BMC Pulmonary Med. 2017;17(1):144, https://doi. org/10.1186/s12890-017-0489-0. 
5. Ying Z, Jingxin Y, Yuxia D, Hong X, Qiyun C, Xuemin G, et al. Protein Expression Profile in Rat Silicosis Model Reveals Upregulation of PTPN2 and Its Inhibitory Effect on Epithelial-Mesenchymal Transition by Dephosphorylation of STAT3. Int J Molecular Sci. 2020;21(4):1189, https:/doi. org/10.3390/ijms21041189.

6. Kaczorowski DJ, Afrazi A, Scott MJ, Kwak JH, Gill R, Edmonds RD, et al. Pivotal Advance: The pattern recognition receptor ligands lipopolysaccharide and polyinosine-polycytidylic acid stimulate factor B synthesis by the macrophage through distinct but overlapping mechanisms. J Leukocyte Biol. 2010; 88(4):609-18, https://doi.org/10.1189/jlb.0809588.

7. Lake FR, Noble PW, Henson PM, Riches DW. Functional Switching of Macrophage Responses To Tumor-NecrosisFactor-Alpha (Tnf-Alpha) by Interferons - Implications for the Pleiotropic Activities of Tnf-Alpha. J Clin Investig. 1994;93(4):1661-9, https://doi.org/10.1172/jci117148.

8. Mon AM, MacKinnon AC, Traktman P. Overexpression of the VRK1 kinase, which is associated with breast cancer, induces a mesenchymal to epithelial transition in mammary epithelial cells. Plos One. 2018;13(9):e0203397, https://doi. org/10.1371/journal.pone.0203397.

9. International Labour Office. Guidelines for the use of the ILO International Classification of Radiographs of Pneumoconioses. Geneva: The Office; 2002.

10. Siyan Z, Dongqing Y, Hongzhuan T. [Epidemiology, 7th. edition]. People's Medical Publishing House; 2012. p. 196. Chinese.

11. Adnan K, Yoonjeong C, Joung Hwan B, Sunmi L, Sun Ha J, Youngja HP. High-resolution metabolomics study revealing L-homocysteine Sulfinic acid, Cysteic acid, and Carnitine as novel biomarkers for high acute myocardial infarction risk.
Metabolism Clin Experim. 2019;104:154051, https://doi. org/10.1016/j.metabol.2019.154051.

12. Fumiya Y, Toru O, Kiyohiro T, Satoshi Y. Novel Urinary Biomarkers for Acute Kidney Injury and Prediction of Clinical Outcomes After Pediatric Cardiac Surgery. Pediatric Cardiol. 2020;41(4):695-702, https://doi.org/10.1007/s00246-01902280-3.

13. Zhang P, Zhang W, Zhang D, Wang M, Aprecio R, Ji N, et al. 25-Hydroxyvitamin D-3-enhanced PTPN2 positively regulates periodontal inflammation through the JAK/STAT pathway in human oral keratinocytes and a mouse model of type 2 diabetes mellitus. J Periodontal Res. 2018;53(3):46777, https://doi.org/10.1111/jre.12535.

14. Mesias P, Thuy TL, Katherine L, Harry KQ, Sarah T, Anuh TG, et al. STAT-3 contributes to pulmonary fibrosis through epithelial injury and fibroblast-myofibroblast differentiation. Faseb J. 2016;30(1):129-40, https://doi.org/10. 1096/fj.15-273953.

15. Shao-Cheng L, Chih-Ming H, Oluwaseun Adebayo B, ChunShu L, Bing-Lan L, Yew-Min T, et al. Ovatodiolide suppresses nasopharyngeal cancer by targeting stem cell-like population, inducing apoptosis, inhibiting EMT and dysregulating JAK/STAT signaling pathway. Phytomedicine. 2019;56:26978, https://doi.org/10.1016/j.phymed.2018.05.007.

16. Yang XL, Zhu XL, Li A, Du XQ, Song YG, Ye Q. [Characteristics of lung function in patients with asbestosis of different stages]. Chin J Industr Hyg Occup Dis. 2016;34(9):687-90, https:// doi.org/10.3760/cma.j.issn.1001-9391.2016.09.013. Chinese.

17. Dipti G, Tanushree G, Ram BS, Mayank S, Uc O, Anand KV, et al. Asbestos-induced lung disease in small-scale clutch manufacturing workers. Ind J Occup Environ Med. 2016;20(2):95102, https://doi.org/10.4103/0019-5278.197533.

This work is available in Open Access model and licensed under a Creative Commons Attribution-NonCommercial 3.0 Poland License - http://creativecommons.org/ licenses/by-nc/3.0/pl/deed.en. 